\title{
New York is centre of US epidemic as Trump pitches in to help
}

\author{
Janice Hopkins Tanne
}

New York, USA

President Donald Trump said he was activating the National Guard to help the three states hit hardest by covid-19.

New York State has more than 15000 cases: 10764 in the city and many others in its northern suburbs. Governor Andrew Cuomo attributed the number to aggressive testing. ${ }^{1}$ The state of Washington has 1996 cases, most in nursing homes in Seattle, ${ }^{2}$ and California has 1787 cases. $^{3}$

The governors of the three states took charge, closing businesses and schools, calling out the National Guard, and searching widely for ventilators and medical supplies. They asked for help from the federal government but on 19 March president Donald Trump said the government is "not a shipping clerk" and that they should be doing much of the work. ${ }^{4}$

Trump changed his approach on 22 March. At a press conference he said he had activated the National Guard in all three states and would send additional medical supplies in the next few days. The National Guard is made up of soldiers who have civilian jobs or are college students while maintaining part time military training and can be called on to deal with emergencies. They will help build medical facilities.

Trump also said he would soon send thousands of gloves, gowns, and masks from the national stockpile to the three states.

In New York City, schools, businesses, theatres, museums, concert halls, houses of worship, sports events, and team sports have been closed or banned. People have been told to work from home. Bars and restaurants are open only for takeout or delivery. Large gatherings are forbidden. Supermarkets, pharmacies, and neighbourhood grocery stores remain open. The subways and buses continue to run although on restricted timetables.

In New York, people may go out for essential errands and for walks in the parks. In Central Park yesterday there were many people and families but almost all were practising social distancing. Mayor Bill de Blasio suggested they keep their healthy strolls short. The "city that never sleeps" is unusually quiet.

In southern California, Los Angeles mayor Eric Garcetti said people needed to follow orders for social distancing. He complained of people going to parks, beaches, and hiking in canyons. "Too many people, too close together, too often. The longer we do that, the more people will get sick, and the more people will die. There's no way to sugar coat that," he said. ${ }^{4}$

1 McKinley J. Coronavirus in NYC: region is now an epicenter of global pandemic. New York Times. 22 March 2020. www.nytimes.come/2020/03/22/nyregion/Coronavirus-newYork-epicenter.html.

2 Kiro 7 News Staff. Coronavirus: Trump approves Washington's emergency disaster declaration, approves use of National Guard. 22 March 2020. www.kiro7.com/news/local/ coranavirus-trump-approves-washingtons-emergency-disaster-declaration/ XIDPHMLVOJAAREQ5YCL75367PU.

3 Willin $\mathrm{P}$, Wigglesworth $\mathrm{A}$, Winton $\mathrm{R}$, et al. LA imposes more restrictions on outdoor activities as coronavirus death toll rises. 22 March 2020. www.latimes.com/california/story/2020 03-22/californias-coronavirus-cases-deaths-rise-newsom.

$4 \quad$ Forgey Q. "We're not a shipping clerk:" Trump tells governors to step up efforts to get medical supplies. Politico (Pavia) 2020. www.politico.com/news/2020/03/19/trumpgovernors-coronavirus-medical-supplies-137658.

Published by the BMJ Publishing Group Limited. For permission to use (where not already granted under a licence) please go to http://group.bmj.com/group/rights-licensing/ permissions 